me that of some 159 tons of "aniline" dyes which passed through their hands as agents last year, 95 per cent. were of Continental make. With reference to the two chief raw materials, benzene and aniline, this same firm estimates that about 75 per cent. of the whole quantity of these products made in England goes to the Continent. ${ }^{1}$

The facts and figures which I have now laid before you must be left to tell their own story-time will not permit me to attempt any analysis of them. The evidence collected will at any rate give a much more forcible idea of the true state of the coal-tar colour industry in this country than has hitherto been attempted, and if this evidence goes against us as a manufacturing nation, it is all the more desirable that our true position should be realised. I find that it is almost impossible to give a correct numerical expression in pounds sterling for the annual value of this industry to the country, as the estimates vary within very wide limits. According to Dr. Perkin, whose opinion on this matter will perhaps carry the greatest weight, the value of the annual output is between $3,000,000 \mathrm{l}$. and 4,000,000l. That the industry is one of considerable importance on the Continent may be gathered from the official returns relating to the German exports. For the following figures $\mathrm{I}$ am indebted to Dr. $\mathrm{H}$. Caro, of the "Badische Anilin und Soda Fabrik," Ludwigshafen on Rhine :-

Exported from Germany, from Fanuary $\mathrm{r}$ to December 31, 1885

Alizarin paste (? per cent.)

A niline and intermediate products $\ldots 4283$ tons

Aniline, \&c., colours ... $\quad \ldots . . . .64645$,

Dr. Caro adds that it is generally believed that about fourfifths of the entire German production are exported.

The magnitude of this branch of chemical industry abroad will be gathered from the fact that a German factory of about the third magnitude consumes at the present time between 500 and 600 tons of aniline annually. According to information recently furnished to me from the two largest of the German factories, the Badische Company employ 2500 working men and officials, and the Hoechst Colour Works (formerly Meister, Lucius, and Brüning) r 600 working men and fifty-four chemists. It must, of course, be borne in mind that in these factories the products are not " aniline" colours only, but alizarin, acids, alkalies, and all chemicals required in this branch of manufacture.

The industry which has been selected for this evening's topic is thus not only an important one in itself, but for us, as chemists, its development is fraught with meaning both scientifically and educationally. In taking up this subject it has not been my desire to exalt the coal-tar colour industry to a position of undue importance, nor do I wish it to be inferred that the remarks which I have made concerning its decadence, or at any rate stagnation, in this country are applicable to this manufacture only. The failure on our part to grasp the true spirit of chemical science in its relation to our manufactures makes itself felt in every industry in which chemistry is concerned. The strength of our competitors is in their laboratories, and not, as here, upon the exchanges. It is only by showing up our weakness in each industry that the state of affairs can be remedied, and our prestige as a manufacturing country restored. If each specialist would do for his industry what I have here attempted to do broadly for the coal-tar colour industry, we should get together a body of evidence which the Royal Commissioners on the depression of trade would do well to take into consideration. We have heard a great deal of late years about the subject of technical education, but the talk has been rather one-sided. We have had utterances from those who, recognising the enormous importance of this subject to the country, have munificently endowed those institutions for the promotion of technical education which are springing up around us; we have had all kinds of schemes from those who are taking upon themselves the duties of technical educators, but it appears to me that we have not heard with sufficient distinctness the voices of those who may be presumed to suffer most from the want of technical education, viz. the manufacturers themselves. I have heard rumours of the existence of a certain class of manufacturer-let us hope a

I According to a later estimate, kindly supplied by Mr. Ivan Levinstein, the quantity of benzene and toluene used in this country amounts to about 500,000 gallons, and that used in Germany to about 2,000,000 gallons annually. A bout half the English production is, however, exported as aniline toluidine, and aniline salt, while Germany converts into colouring-matters at least $1,600, \infty 00$ gallons of these hydrocarbons. rare species-who declares that science is no use to him, and that he can get along better without it. I must confess that I never met this individual in the flesh, but I know that he exists in some of our manufacturing centres. As a species he is, however, doomed to extinction in the struggle with his competitors, and we may consider him out of court in the discussion of schemes of technical education. It is now generally admitted that the days of empiricism have passed away, and most manufacturers admit that present success and future development depend upon a proper recognition of technical, i.e. of applied science. But unless the manufacturers themselves speak loudly on this question, the voices of those who wish to promote scientific education may be drowned by the clamour of mere theorists.

In no other department of our manufactures is the want of technical science more felt than in the chemical industries. We not only see this in the greater development of these industries abroad, but in some of our most successful factories here-and this applies more especially to the coal-tar colour industryforeign chemists are employed, and as I have lately been informed by a well-known manufacturer, it is even impossible to get the necessary plant properly made in this country. There is no doubt that the recondite character of the truths of chemical science, as compared with the more obvious truths of mechanics and physics, has much to do with the want of popularity of this branch of knowledge, and is responsible for the circumstance that our science is regarded with comparative indifference until some branch of manufacture is in extremis. In our national characteristic of being "practical," we are apt to become shortsighted in our manufacturing policy, and to recognise only actualities, to the exclusion of the potentiality conferred upon a nation by a broader scientific culture.

In conclusion, I have to express my thanks to Messrs. Brooke, Simpson, and Spiller; Messrs. Burt, Bolton, and Haywood; and to the British Alizarin Company for the fine series of specimens now exhibited. For the beautiful specimens illustrating the Continental manufacture, I am especially indebted to the Badische Anilin and Soda Fabrik, of Ludwigshafen on Rhine, and to the Hoechst Colour Works. The series of patterns dyed with known weights of fifty distinct coal-tar colours were prepared by Mr. Ivan Levinstein for the lecture recently delivered at the Royal Institution by Sir Henry Roscoe, to whom I am indebted for being able to show them on the present occasion.

\section{DRYING UP OF SIBERIAN LAKES}

THE rapid drying up of lakes in the Aral-Caspian depression, in so far as it appears from surveys made during the last hundred years, is the subject of a very interesting and important paper contributed by M. Yadrintseff to the last issue of the Izvestia of the St. Petersburg Geographical Society (vol. xxii. fasc. I). Two maps, which will be most welcome to physical geographers, accoinpany the paper. One of them represents the group of lakes Sumy, Abyshkan, Moloki, and Tchany, in the Governments of Tobolsk and Tomsk, according to a survey made in 1784 . The other represents the same lakes according to three different surveys made during our century, in 1813 to 1820 , in 1850 to 1860 , and finally in 1880 , and it shows thus the rapid progress of drying up of these lakes. There are also earlier maps of Lake Tchany, which represent it as having very many islands (Pallas estimated their number at seventy), but they are not reliable. As to the map of 1784 , no cartographer, accustomed to distinguish "nature-true" maps from fancy ones, would hesitate in recognising it as quite reliable as to its general features. It is also fully confirmed by the ulterior detailed surveys dating from the beginning of our century. It appears from this series of four maps, dating from different periods, that the drying up has gone on at a speed which will surely appear astonishing to geographers. The group of lakes consisted of three large lakes-Sumy, Abyshkan, and Tchany, with a smaller lake, Moloki, between the two latter. Lake Tchany (the largest of the three) has much diminished in size, especially in its eastern and southern parts; but the greatest changes have gone on in the other lakes. Whole villages have grown on the site formerly occupied by Lake Moloki, which had a length of twenty miles at the end of last century, and now is hardly three miles wide. Of Lake Abyshkan, which had a length of forty miles from north to south, and a width of seventeen miles in the earlier years of this century, and whose surface was estimated at 530 square miles, 
only three small ponds have remained, the largest of them being hardly one mile and a half wide. The drying up has been going on with remarkable rapidity. Even twenty-five years ago there were several lakes ten and ei ght miles long and wide, where there are now but little ponds. Lake Tchebakly, which was represented in 1784 as an oval forty miles long and thirty miles wide, has an elongated irrezular shape on the map of the beginning of our century; it measures, however, still forty miles in length, and its width varies fro $n$ seven to twenty miles; while several small lakes to the east of it show its former extension. Thirty years later we find in the same place but a few small lakes, the largest of which hardly has a length and width of three miles; and now, three small ponds, the largest of them having a width of less than two miles, are all that remain of a lake which covered about 350 square mile; a hundred years ago. The same process is going on throughout the lakes of West Siberia, and throughout the Aral-Caspian depression. No geologist doubted upon, but we cannot but heartily thank M. Yadrintseff for having published documents which permit to estimate the rapidity of the process.

P. K.

\section{UNIVERSITY AND EDUCATIONAL INTELLIGENCE}

WE understand that $\mathrm{Mr}$. Granville Cole has been appointed to the Professorship of Geology at the Bedford College, London, and Miss C. A. Raisin to the Demonstratorship in Butany at the same institution.

\section{SCIENTIFIC SERIALS}

THE Fournal of Botany.-The number for July commences with the first part of an important article (illustrated), by Messrs. Roy and Bisset, on Japanese Desmids, chiefly obtained from a lake in the Island of Yesso. The majority of the forms obtained are cosmopolitan, but some of them of great rarity in Europe. There are also some new species. Papers follow on British Rubi, on the Rubi of Somersetshire, and on the flora of St. Kilda.

American Fournal of Science, July.-Memorial of Edward Tuckerman, by Asa Gray. This botanist, who was born in Boston, December 7, 1817, and died March 15, 1886, was distinguished especially in the field of lichenology, to which he devoted most of his life. He was the author of a "Synopsis of the Lichens of New England, the other Northern States, and British America," of "Lichenes Americæ Septentrionalis exsiccati" (3 vols.), and many other papers on this branch of botany, in which he has left behind him no superior.- Notes on American earthquakes (No. 15), by Prof. C. G. Rockwood, jun. This fifteenth paper of the series gives a summary of such information as the author has been able to gather on the earthquakes of North and South America during the year 1885. It tabulates seventy-one shocks, classed according to their intensity as very light, light, moderate, strong, severe, or destructive. Of these as many as thirty-four occurred on the Pacific coast of the United States, where the Bay of San Francisco appears to be a chief centre of seismic disturbance.-Observations on the Tertiary and Grand Gulf of Mississippi, by Dr. Otto Meyer. The author finds no place where Grand Gulf strata overlie the Marine Tertiary, although there are two districts where strata undistinguishable from unquestioned Grand Gulf are overlain by Marine Tertiary. The Grand Gulf is not, generally speaking, a marine formation, for it contains fresh-water shells. In Eastern Mississippi occurs a thick and extended marine greensand formation parallel to the strata immediately below the Claiborne profile. Its fauna is Claibornian, but approaches the Jacksonian. - Notes on the volcanic rocks of the Republic of Salvador, Central America, by Arnold Hague and Joseph P. Iddings. This study is based on specimens gathered by Mr. W. A. Goodyear in the course of his explorations in Salvador. They are of a highly diversified character, ranging from very basic to highly acidic forms, from rocks rich in olivine to others abounding in quartz, and may be classified under the heads of basalt, pyroxene-andesite, hornblende-pyroxene-andesite, hornblende-mica-andesite, dacite, and possibly rhyolite, basalt and dacite being best represented. Nearly all have their counterpart in Nevada, although there occur many varieties in Nevada not found in the limited serie; from Salvador.The genus Strephochetus: distribution and species, by Henry
M. Seely. Since reporting last fyear the presence of the fossil sponge, Strethochetus occellatus, at one or two places in Vermont and New York, the author has traced it to many other districts in those States. To the type of the genus, S. occellatus, he now also adds three new species-S. brainerdi, $S$. atratus, and $S$. richmondensis. - Preliminary report on the geology of the Cobscook Bay district, Maine, by. N. S. Shaler. This paper, published by permission of the Director of the U.S. Geological Survey, gives a portion of the general results of two months' exploring work on the shore-line of Cobscook Bay during the summer of 1884 . The fossiliferous strata have a special interest as throwing light on the position of the shore-line in past times. A conglomerate apparently of the Clinton or Niagara age on the west side of South Bay seems to show that the shore in this district was not far away during a portion of the time when the Cobscook series was forming. In the age of the Perry section there is also evidence that the coast was near its present position and that the rocks exposed to erosion were chiefly of the Laurentian epoch. - On the well-sperometer, by Alfred M. Meyer. The instrument here described, with numerous illustra. tions, has for the last ten years been used by the author in his laboratory for the purpose of measuring the radius of curvature of a lens of any linear aperture.-On some general terms applied to metamorphism and to the porphyritic structure of rocks, by James D. Dana. The three recognised forms of metamorphism are described and characterised as :(I) crystallinic; (2) paramorphic; (3) metachemic. A full terminology of porphyritic varieties is given, based in plan on such terms as orthophyre, augitophyre, \&c.

Bulletin de l'Académie Royale de Belgique, May.-On the transparency of platina, by Ed. van Aubel. After ascertaining by experiment that a sheet of cobalt, iron, or nickel obtained by electrolysis on a transparent sheet of silver, is not really transparent, as is now generally assumed, the author here endeavours to settle the question as regards mirrors of platina chemically produced, that is, by a deposit of platina on a sheet of glass, and the transparency of which is admitted by Kundt. Working with a large mirror supplied by Paul Lohmann of Berlin, from whom Kundt also obtained those used by him, M. van Aubel found, by means of spectroscopic observations, that the metal of these mirrors is not really transparent, the light merely filtering through the interstices left between the particles of platina deposited on the surface. - A contribution to the study of the salts of platina, by M. Eugène Prost. The author deals especially with the action of nitric acid and of perchloric acid on platinic hydrate, and with the action of nitric acid on the precipitated bisulphuret of platina, his object being to form the so-called normal platinic nitrates, perchlorates, and sulphates. Failing to obtain these substances, he endeavoured to get double salts of normal composition by combining them with alkaline salts having corresponding acids. The results show that all the compounds thus obtained still correspond with basic platinic salts, so that it would so far appear that a normal platinic nitrate cannot be obtained,-On the unstable equilibrium of the surfacelayer of a fluid, by G. van der Mensbrugghe. The absolute in. stability of surface-layers exposed to the free action of the atmo sphere is demonstrated on theoretical grounds. From this theory the author proposes in another paper to deduce the existence of superficial tension on the free surface of a fluid, or on the surface common to two fluids, or to a fluid and solid, thence deriving a rational explanation of the phenomenon of evaporation.--On the heat of the alloys of lead and tin, by W. Spring. Continuing the researches of Ermann, Rudberg, Regnault, Wiedmann, and others, the author seeks to determine for restricted intervals of temperature the total heat of these alloys relatively to that of their constituents. Further light is thus thrown both on the constitution of these bodies, and on the question why their point of fusion is lower than that of their constituents.

Rendiconti del Reale Istituto Lombardo, June.-On some unconscious intervals in a co-ordinate series of psychic acts, by Tito Vignoli. The object of this essay is to ascertain experimentally whether in the co-ordinate exercise, or logical sequence, of thought, it sometimes happens that some of the connecting links of the argument are supplied unconsciously. Several instances are quoted, together with the author's personal experience, showing that this really is the case. It is incidentally argued that, in its complexity, the brain is a large organ of compensation, so that, if any of its parts in which special functions are localised become disturbed or injured, these may, within 